\title{
Payment of Diyat in Pakistan: Exploring the Missing Islamic Spirit
}

\author{
* Dr. Muhammad Asad, IPFP Fellow (Corresponding Author) \\ ** Dr. Barkat Ali, Assistant Professor \\ *** Hafiz Muhammad Usman Nawaz, Assistant Professor
}

\begin{abstract}
Though the Islamic Republic of Pakistan (Pakistan) as established in 1947, adopted the then British oriented existing laws, it was confirmed that appropriate modification will be made in these laws. Therefore, among others, the criminal laws including Pakistan Penal Code, 1860 (PPC) have been amended particularly to bring its provisions in conformity with Islamic Injunctions. In this context, in addition to other matters of the offenses affecting human life, the provisions of Diyat have been inserted in PPC. However, the law of Diyat as introduced in PPC is not all-inclusive. On the aspect of responsibility regarding the payment of Diyat, in case of incapacity of the offender, the law of PPC as amended in Islamic context is somehow still incomplete. As such, this situation is affecting the rights of the parties. The present law of Diyat as provided in PPC, indeed, is lacking the important aspect 'Aqilah'. The insertion of provisions of 'Aqilah' in the PPC, may make the law of Diyat in the true sense of Islamic Injunctions, and consequently, the currently arising issues of non-payment of Diyat money particularly in case of offender's poverty, maybe settled down, and it ultimately will contribute for upholding the Rule of Law in criminal administration justice system of Pakistan. This is a doctrinal and analytical based study that focuses on the relevant literature either directly or indirectly related to the research topic. It engages the investigative deliberation of both types of primary and secondary sources. Such a way of deliberating the currently prevailing situation will put our study toward a result-oriented conclusion with suitable suggestions on the topic at hand.
\end{abstract}

Keywords: Diyat, Pakistan Penal Code, Aqilah.

\section{Introduction}

Though in the early constitutional history of Pakistan, the British oriented legal system was adopted (Indian Independence Act, 1947, Section 8(3); Adoption of Exiting Laws Order, 1947; Adoption of Central Acts and Ordinances Order, 1949), the number of laws has been modified following Islamic sprit. Among others, the amendments made in the Pakistan Penal Code, 1860 (PPC) are of great significance. PPC is the substantive criminal law defining and providing the punishments for different types of offenses. This law was initially promulgated in 1860, and was adopted for the newly born state of Pakistan in 1947, and has been amended several times (Criminal Law (Amendment) Act, XXIII of 2002; XXVI of 2011; XXV of 2011; XX of 2011; I of 2010; Act, 2006; I of 2005; LXXXV of 2002; LXXXVI of 2002).

In 1997, PPC was amended to bring it in consonance with the Islamic injunctions, and such amendment was made through the Criminal Law (Amendment) Act, 1997. Through this amendment in addition to other matters of offenses on the human body, the provisions of Diyat concerning the offenses of murder, and Isqat-i-Janin have been inserted. Of course, critics have commented that this modification is not all-inclusive following Islamic injunctions. The study undertaken is intended to explore the true Islamic scope of Diyat. For this objective, this study critically contemplates a question that 'What is missing from Islamic viewpoint in the law of Diyat as provided for the punishment of different offenses in the PPC after an amendment made in 1997?'

\section{Objectives of the Research Study}

This study provides the appraisal of the law of Diyat concerning the offenses of murder, hurt, and Isqat-i-Hamal and Isqat-i-Janin as provided in PPC, in Islamic perspective. This research is intended to discuss all aspects of the law of Diyat comprehensively and identify the missing aspect, if any, of

* HEC, Department of Law, The Islamia University of Bahawalpur Email: mu.asad@ @iiu.edu.pk

** Department of Law, The Islamia University of Bahawalpur Email barkatali27@ gmail.com

*** Department of Law, International Islamic University, Islamabad Email: usman.nawaz@iiu.edu.pk 
Diyat which otherwise might be the basic ingredient of it in Islamic perspective. The objective of the study undertaken is to confirm the intent and attempt of the legislature which proclaimed the amending of the substantive criminal law relating to human life according to the injunctions of Islam. The study may contribute to establishing the Rule of Law even for the alleged offender undergone for a punishment passed in absence of payment of Diyat money. The study undertaken will also complement the existing knowledge on the issue in question as a guideline for all concerned.

\section{Law of Diyat in Pakistan: Contemporary and Islamic Version:}

\section{A Critical Appraisal}

In this section, our study focuses on the provisions of Penal Code 1860 contemporary prevailing concerning Diyat along with the offenses for which this punishment may be awarded. Afterward, this study deliberates the Islamic viewpoint and finally, a discussion is made on the missing aspect of Diyat and its role for the Rule of Law for the alleged offenders.

\section{Diyat in PPC: Concept; Value; Punishment}

\section{Concept of Diyat}

Diyat, indeed, is an Islamic concept of compensation for victims, and punishment for offenders. It was, however, introduced in 1997, for the first time, in substantive criminal law of PPC, 1860, (Criminal Law (Amendment) Act 1997(II of 1997). Diyat has been defined as "the compensation ...payable to the heirs of the victim" (PPC, 1860, Section 299 (e) ). It is, a monetary punishment as described in Section 54-A, PPC, 1860, and is awarded in particular circumstances where the offender of murder cannot be punished with death as Qisas.

In the definition, the words "heirs of victim' have been used and not the words 'the victim or his heirs'. This means that Diyat is a compensation payable only in cases of Qatl and not in other cases. Therefore, such a sentence is awarded in the offenses of Qatl-i-Amd, Qatl Shibh-i-Amd, Qatlbis-Sabab, and Qatl-i-Khata which occur by neglectful driving and Isqat-i-Janin which causes ultimately the death.

\section{Diyat Value}

According to PPC, the amount of Diyat is not permanent, except equated with a current market price of a fixed amount of 30,630 grams of Silver. Therefore, it has been left to the Court's discretion to fix the value of Diyat which may be different from case to case. In this context PPC, however, has provided a standard for the amount of it. According to the PPC, the court may determine the value of Diyat, and while fixing such value it will keep in mind the Islamic teachings and financial circumstances of the offender. However, this amount shall not be than the value of thirty thousand six hundred and thirty grams of silver (PPC, 1860, Section 323 (1)). In this context, the Federal Government yearly declares the value of Silver for deciding the Diyat value (PPC, 1860, Section 323 (2) ). Recently the government has increased the value of Diyat (blood-money) from Rs. 23, 20,202 to Rs. 27, 77, 353 for the fiscal year 2020-2021(Notification Ministry of Finance, 2020).

\section{Diyat as Punishment}

There are certain types of sentences that may be awarded to a guilty person proved of any offense under PPC, 1860. Diyat is one of those punishments and has been provided in Section 53 of PPC, 1860. The sentence of Diyat may be awarded in cases namely, murder and Isqat-i-Janine, etc. These offenses come within the category of 'offenses affecting life' (PPC,1860, Sections 299- 338-H). In these provisions, in addition to life-related offenses, the said offenses have been defined, and different sentences including Diyat have been described for each of such offenses. As our study is concerned with payment of Diyat, so only the law relating to Diyat is discussed in the next lines.

\section{Diyat in Murder Cases}

The offense of Murder as provided in PPC has four different forms including Qatl-i-Amd, Qatl Shibhi-Amd, Qatl-i-Khata, and Qatlbis-Sabab, (PPC, 1860, Sections, 300,315, 318, 321). In the case of Qatl-i-Amd, Diyat is awarded, "Where an offender ... is not liable to Qisas under Section 306 or the Qisas is not enforceable under clause (c) of Section 307(PPC, 1860, Section 308(1)).

Generally, this Diyat money is to be paid by the offender himself. However, "where the offender is minor or insane, Diyat shall be payable either from his property or, by such person as may be determined by the Court" (PPC, 1860, Section 308(1)). Furthermore "where the Qisas is not enforceable under clause (c) of Section 307, the offender shall be liable to Diyat only if there is any Wali other than offender" (PPC, 1860, Section 308(1)). 
In Qatl-i-Amd, Wali may waive the right of Qisas (PPC, 1860, 309 (1)). However, in case the Wali is more than one and among those anyone does not forego his right of Qisas, shall receive his share of blood money which is awarded as punishment (PPC, 1860, Section 309(2)).

Qatl-i-Amd may be compounded and resultantly a sane and adult Wali may accept Badl-iSulh (PPC, 1860, Section 310(1)). For such type of Badl-i-Sulh, the offense of Qtal-i-Amd may also be compounded by a Wali of insane or minor's Wali, and even by the Government as Wali. (PPC, 1860, Section 310(2\&3)). However, "Where the Badl-i-Sulh is not determined or is a property or a right the value of which cannot be determined in terms of money under Shari'ah, the right of Qisas shall be deemed to have been compounded and the offender shall be liable to Diyat" (PPC,1860, Section 310(4)).

If a Wali, after waiving Qisas under Section 309 or compounding of Qisas under Section 310, committed Qatl-i-And it shall become an offense. Such Wali is liable to a sentence which may be in term of Diyat money provided that if he was unknown to such waiving or compounding. (PPC, 1860, Section $312(b))$.

Diyat may be imposed on the offender of Qatl Shibh-i-Amd and Qatl bis-Sabab (PPC, 1860, Sections 316,322). The offense of Qatl-i-Khata and Qatl-i-Khata by rash or negligent driving may also liable to Diyat (PPC, 1860, Sections 319,320)

\section{Diyat as Punishment in Isqat-i-Janin Cases}

Isqat-i-Janin is an offense as defined in PPC that, "Whoever causes a woman with child some of whose limbs or organs have been formed to miscarry, if such miscarriage is not caused in good faith to save the life of the woman, is said to cause Isqat-i-Janin" (PPC, 1860, Section, 338-B). A woman herself may be the offender of such offense when she miscarries herself (PPC, 1860 Section, 338-B). Such offense may be liable to the Diyat. The amount of Diyat money in such case will be onetwentieth of the Diyat provided that the child is born deadly (PPC, 1860, Section, 338(C) (a)). However, full Diyat is to be paid where the child is born alive and dies afterward because of any act of the offender (PPC, 1860, Section 338 (C) (b).

If there is more than one child in the womb of the woman, a separate Diyat for every such child is imposed on the offender (PPC, 1860, Section 338 (C)). Furthermore, if someone has caused any hurt to the woman during Isqat-i-Janin, and resultantly she dies, such person may be sentenced with Diyat (PPC, 1860, Section 338 (C).

\section{Payment of Diyat}

The payment of Diyat is provided in Section 331 PPC. According to this section Diyat money may be paid as a whole or in installments. However, it must be paid within three years since the passing date of final judgment (PPC, 1860, Section 331(1) PPC. However, the failure of payment of Diyat money in such a way as detailed above, the convict has to face some consequences. He may be kept in jail where he shall be dealt with in the manner as he is punished to simple imprisonment. However, he may be released on the payment of full Diyat or may be released on bail on furnishing security equal to the Diyat money by the approval of the Court (PPC, 1860, Section 331(2)). Of course, in case of death of the convict before the payment of Diyat money in full or any part thereof, such amount of money is to be recovered from his estate (PPC, 1860, Section 331(3)).

\section{Repercussions of Non-Payment of Diyat on Parties Rights}

The Consequences of non-payment of Diyat are very severe as discussed above. The reason for nonpayment may be the intentional evasion or incapacity to pay, and in both of these situations, the rights of the parties may not be protected properly. This situation, of course, demonstrates the infringement of fundamental rights, and ultimately the absence of Rule of Law in the administration of the justice system.

In case of the first reason, the confining the offender in jail till the payment is justified as despite the paying capacity for Diyat, escaping from payment, amounts to the defiance of the order of the court. This is both a violation of law and an infringement of the right of the heirs who have the right to receive Diyat awarded in case of death of their ancestor. This situation warrants that the victim must be kept behind the bar till the payment of Diyat for which he has the paying capacity.

Of course, the second reason 'incapacity to pay' demands either of the following measures. First, payment of Diyat should be made by the heirs of the offender. Secondly, State should take the responsibility for the payment of the Diyat on the part of the poor citizen-offender. In both of these measures, we may have a dual opportunity of ensuring the victim's genuine compensation and 
protecting the liberty of a needy poor citizen. Otherwise, such a situation may force the alleged offender to be jail depriving him of his fundamental right of liberty just because he is poor. Unfortunately, the law is silent as to the period for such confinement which consequently may be indefinite.

Of course, to tackle the issue of the payment of Diyat, the government has passed the rules of Diyat. A scheme of soft loan has been introduced which stated that if the convict fails to return the loan he is again kept in jail (Diyat, Arsh and Daman Fund Rules 2007, Rules, 6 \& 9). Mr. Justice Faiz Isa has also raised a question, concerning rule 11 of the same law which talks about part payment and the terms and conditions to release the convict, that what is meant by part payment, and what are the terms and conditions to be forced. He further said that whether the court can pass the order of detention in case the convict is not able to payday. (Shakeel Abbas v. State, 2018). It is, therefore, concluded that the said rules 2007 is not the exact and appropriate solution to the issue.

In such a state of affairs, there is a need to find out the possible way to compensate the Vitim's interest of Diyat money along with the convict's right of liberty. For such a resort, the concept of Aqilah in Islamic law may be evoked particularly where offenses affecting the human body are proclaimed to be dealt with by the injunction of Islam, and for the interpretation and application of the relevant provisions, Court shall seek the guidance from by directives of Shari'ah.

\section{Diyat in Islamic Law: The Concept of Aqilah}

Justice is the ultimate objective of Islamic criminal law. Islam secures the interest of victims in all cases. The Holy Quran says that "Whosoever kills a believer by mistake, then a believing slave has to be freed, and the blood money (Diyat) must be paid to his family" (Al-Quran, An-Nisa, 92). In another verse, it says that "whosoever kills a believer deliberately, his reward is japan um" (hell) (Al-Quran, An-Nisa, 93). The study of Islamic criminal law revealed that the wrongdoer must be penalized in whatsoever form suits him and the victim must be compensated in all cases whether the convict is poor or rich and whether the guilt is committed intentionally or unintentionally. Even in case the wrongdoer is poor and cannot pay the diyat, then the diyat shall be paid by his aqilah collectively.

The term Akilah is derived from the Arabic word aqal. The literal meaning of the equation is to detain or restraint something. In this sense, the aqal is called equal because it restraints or stops humans from indulging in harmful activities (Ibn Manzor, 1993), and Aqilah is called taqiyah because by paying the diyat they restraint the killer being oppressed or abused by the heir of victim. (Ibn Uthaimin, 2007).

In Islamic law, the term Aqilah was used for those male combatants whose names were enlisted in the official register (Al-Sarakhsi, p. 256). The term Aqilah is also defined as male paternal relatives of wrongdoers who are called Asabahin Islamic law (Almawardi, 1999).

Thus, the Akilah, in the light of the above-mentioned definitions given by classical jurists, is the group of particular class who are collectively responsible for the wrongful act of the member of that very class.

\section{Origin of Aqilah}

It is pertinent to note that Arab societies were divided into different tribes. These tribes were the ones who used to support and help each other in difficult and hard cases. Hence, if any fellow had been killed unintentionally, the tribe of the killer, who is collectively called Akilah, had to pay the Diya to the heirs of the deceased. This Akilah system was accepted by our prophet (PBUH) as a part of Shari'ah.

In His (PBUH) reign, two females fought each other and one hit the other with a stone. Eventually, the female hit by the stone died and her fetus was miscarried. The relatives of the victim came to the prophet (PBUH) to make him decide the matter. The prophet (PBUH) decided that a slave, either male or female, was paid as Diyat of miscarriage and the diyat of deceased women was paid by the Aqilah (Bukhari, 2001) This hadith is evidentially establishing the concept of Aqilah. As $\mathrm{He}$ (PBUH) did not specify the amount of what each individual would pay, so it on the ruler to decide the amount that each member would pay keeping in view their financial conditions. The institute of Aqilah was further developed by the companions of the prophet when Hadhrat Umer (RA) decided that Akilah would pay the diyat in three consecutive years (Albayhaqi, 1991).

\section{Need to establish the institution of Aqilah}

Since the trends have been changed and our family system has been dissociated. Hence, the institute of Aqilah is no more exciting now a day. On the other hand, the unintentional death rate is getting 
greatly up day by day due to an increase in traffic accidents and medical injuries that occur from the unintentional mistakes of drivers and medical professionals. Most of the wrongdoers in these accidents and injuries are poor. They cannot pay the entire amount of Diya as the amount is very huge. Resultantly, the blood of victims gets wasted without any reciprocal consideration for their heirs. Therefore, it is of utmost need to re-establish the institute of Akilah on modern parameters. So that, the interest of the victim's heirs could be protected and the poor wrongdoer could be relieved from the heavy burden of the day.

\section{Modern Application of Aqilah}

Since Islam values human life and secures the interest of the victim, therefore; it is necessary that the government, by way of legislation, incorporate the concept of Akilah in PPC to secure the blood money to the heirs of the victim. Also, the relevant authorities should work to spread the spirit of cooperation and solidarity among the different groups and associations whose members have a social bond.

In the absence of the classical form of Akilah, it is required to constitute the new modern forms of Aqilah based on allies and joint bonds. The International Islamic Fiqh Academy has proposed the various modern forms to re-establish the institute of Akilah.

i) Islamic insurance or takaful which provides a system of bearing the blood money for the members of that very insurance and takaful.

ii) Unions and associations which are established among the same profession. These unions and associations are supposed to incorporate in their statutes provisions and mechanism about the Aqilah bearing the risks of any casualty occurred to any member of that very union of association.

iii) Special funds created by different public and private organizations to build solidarity and cooperation among their members (Resolution on Aqilah, 2005)

In this regard, the Academy also emphasizes activating charity funds through zakat, waqf, will, and other donations to contribute to bearing the blood money resulting from unintentional killing. The academy also proposes that if the deceased has no aqilha, then the Bayt Al-Mal (the public treasury) would be assigned the task of covering blood money to provide the compensation for the heirs of the victim (Resolution on Aqilah, 2005))

\section{Conclusion}

To conclude, it is said that the insertion of the provisions related to Diyat in PPC is a milestone in the criminal administration justice system of Pakistan. The law is primarily according to the injunctions of Islam. However, the absence of the concept of Aqilah which is an important factor dealing with the payment of Diyat, is affecting the true enforcement of Diyat. The convicts punished with Diyat sometimes may have no capacity to pay Diyat money. In such a situation the rights of both of the parties, i.e., victim and offender may not be protected properly in the present scenario of the law of Diyat. The victim is deprived of the due compensation as awarded by the court. Whereas, the offender will have to face jail for an indefinite period just because of his poverty. This situation, of course, demonstrates the infringement of fundamental rights of fair justice and liberty of both parties respectively and ultimately affected the Rule of Law in the administration of the justice system in Pakistan. For escaping such type of lacuna in the law, the concept of Aqilah as developed in Islamic jurisprudence may be an effective instrument. Had the concept of Aqilah given in PPC, the poor offender would not have been kept in jail unjustly and the heir of the victim would have not been deprived of receiving the blood money of the deceased.

Therefore, it is suggested that the provision regarding Aqilah should be inserted in PPC to avoid the consequences of non-payment of Diyat.

\section{References}

\section{Legislation}

The Criminal Law (Amendment) Act, II of 1997.

The Adoption of Central Acts and Ordinances Order, 1949.

The Adoption of Exiting Laws Order, 1947.

The Criminal Law (Amendment) Act, 2006.

The Criminal Law (Amendment) Act I of 2005.

The Criminal Law (Amendment) Act I of 2010.

The Criminal Law (Amendment) Act XX of 2011. 
The Criminal Law (Amendment) Act XXV of 2011.

The Criminal Law (Amendment) Act XXVI of 2011.

The Criminal Law (Amendment) Act, XXIII of 2002.

The Diyat, Arsh and Daman Fund Rules, 2007.

The Indian Independence Act, 1947.

The Pakistan Penal Code, 1860.

\section{Case-Law}

Shakeel Abbas v. State [2018.]Jail Petition, No. 887.

\section{Books}

Albayhaqi.(19191). Marif-ul-Sonan, Jamia Dirasat-ul-Islamiya, Karachi, Vol 12.

Almawardi. (1999). Alhaviul Kabeer, Darul kotoulllmiyyah, vol12.

Al-Quran, An-Nisa, 92, Translation by Mufti Taqi Usmani.

Al-Sarakhsi. (1993). , Kitab al-Mabsut, Dar ulmarifa, Beirut, vol7.

Bukhari (2001). Sahihul Bukhari, vol.11.

Ibn Manzor. (1993).Lisanul Arab. Dar Sadir, Beruit, v 11, p 459.

Ibn Uthaimin. (2007). Al-Sharh Al-Mumti. Dar Ibn al-Jauzi, Vol 14.

Website

Resolution on Aqilah. (2005). Retrieved on 12-08-2020 from https://www.iifa-aifi.org/2176.html 